$\begin{array}{rr}\text { FIT(1)PATOLOGI } & \text { Volume } 13, \text { Nomor 3, Mei } 2017 \\ \text { IN DONESIA } & \text { Halaman 73-80 } \\ \text { ISSN: } 0215-7950 & \text { DOI: } 10.14692 / \text { jfi.13.3.73 }\end{array}$

\title{
Identifikasi Patotipe Xanthomonas oryzae pv. oryzae dari Tanaman Padi di Sulawesi Selatan
}

\section{Pathotype Identification of Xanthomonas oryzae pv. oryzae Isolates from South Sulawesi}

\author{
Asysyuura ${ }^{1}$, Abdjad Asih Nawangsih ${ }^{1 *}$, Kikin Hamzah Mutaqin ${ }^{1}$, Sudir $^{2}$ \\ ${ }^{1}$ Institut Pertanian Bogor, Bogor 16680 \\ ${ }^{2}$ Balai Besar Penelitian Tanaman Padi, Sukamandi
}

\begin{abstract}
ABSTRAK
Xanthomonas oryzae pv. oryzae penyebab penyakit hawar daun bakteri (HDB) merupakan salah satu faktor penting dalam penurunan produksi padi. Bakteri patogen ini dikenal memiliki banyak patotipe yang dapat menyebabkan kendala dalam upaya pengendalian. Penelitian dilakukan untuk menentukan penyebaran patotipe $X$. oryzae pv. oryzae di beberapa kabupaten di Sulawesi Selatan. Pengelompokan patotipe mengikuti metode Kozaka yang didasarkan pada respons varietas tanaman padi diferensial. Infeksi $X$. oryzae pv. oryzae dari sampel tanaman padi bergejala dideteksi dengan teknik PCR menggunakan pasangan primer spesifik XOR-R2/XOR-F. Dari 36 galur bakteri, sebanyak 29 galur bakteri positif $X$. oryzae pv. oryzae yang terbagi atas 3 patotipe, yaitu patotipe III (6 isolat), patotipe IV (21 isolat), dan patotipe XII ( 2 isolat). Hasil identifikasi menunjukkan X. oryzae pv. oryzae patotipe IV merupakan patotipe yang tersebar luas di Sulawesi Selatan.
\end{abstract}

Kata kunci: hawar daun bakteri, PCR, varietas diferensial

\begin{abstract}
Xanthomonas oryzae pv. oryzae is the causal agent of bacterial leaf blight (BLB), one of important constraint in rice production. The pathogen is known to have many pathotypes which caused difficulties in disease control. This research was conducted to determine the distribution of $X$. oryzae pv. oryzae's pathotypes in seven districts in South Sulawesi. Grouping of pathotypes was performed according to Kozaka method, i.e. based on the response of differential rice varieties. Infection of $X$. oryzae pv. oryzae was confirmed by PCR using specific primers XOR-R2/XOR-F. Out of 36 isolates, 29 isolates were identified as $X$. oryzae pv. oryzae which belong to pathotype III (6 isolates), pathotype IV (21 isolates), and pathotype XII ( 2 isolates). This result indicated that $X$. oryzae pv. oryzae pathotype IV was distributed widely in South Sulawesi.
\end{abstract}

Key words: bacterial leaf blight, differential varieties, PCR

*Alamat penulis korespondensi: Departemen Proteksi Tanaman, Fakultas Pertanian, Institut Pertanian Bogor. Jalan Kamper, Kampus Dramaga IPB, Bogor 16680

Tel : 0251-8629364, Faks: 0251-8629362 ; Surel: asnawangsih@yahoo.com 


\section{PENDAHULUAN}

Bakteri Xanthomonas oryzae pv. oryzae penyebab penyakit hawar daun (HDB) pada padi diketahui memiliki keragaman patotipe. Keragaman patotipe ini menyebabkan mudah patahnya suatu ketahanan varietas tanaman padi (Sudir et al. 2012). Penggunaan varietas padi yang tahan terhadap infeksi patogen $X$. oryzae pv. oryzae masih menjadi komponen utama dalam tindakan pengendalian. Selain efektif, penggunaan varietas tahan juga lebih murah dan mudah dilakukan oleh petani. Permasalahan yang muncul dalam penggunaan varietas tahan ialah terbentuknya patotipe baru seiring dengan perkembangan varietas yang digunakan. Suryadi et al. (2006) melaporkan bahwa $X$. oryzae pv. oryzae memiliki tingkat variabilitas virulensi dan pembentukan galur baru di lapangan yang menyebabkan terjadinya pergeseran patotipe.

Penyakit HDB menjadi salah satu penyakit padi yang penting dan tersebar di berbagai ekosistem penghasil padi di Indonesia, termasuk Sulawesi Selatan. Kehilangan hasil karena $X$. oryzae pv. oryzae dapat mencapai 50-70\% (Mew et al. 1982). Pada umumnya petani mengandalkan penggunaan varietas padi yang tahan untuk mengendalikan penyakit tersebut. Pengetahuan tentang jenis patotipe yang ada di wilayah tersebut menjadi penting untuk diketahui sebagai dasar penentuan langkah pengendalian yang tepat. Berdasarkan hal tersebut, penelitian ini dilakukan untuk menentukan sebaran patotipe bakteri $X$. oryzae pv. oryzae di pertanaman padi di wilayah Sulawesi Selatan. Teknik identifikasi secara molekuler dilakukan untuk mendapatkan galur yang positif $X$. oryzae pv. oryzae dengan tingkat akurasi yang lebih baik.

\section{BAHAN DAN METODE}

\section{Pengambilan Sampel Tanaman Padi}

Sampel tanaman padi diambil dari 7 kabupaten di Sulawesi Selatan, yaitu Kabupaten Barru, Bone, Pangkep, Maros, Takalar, Jeneponto, dan Bantaeng. Sampel yang diambil berupa daun padi yang bergejala hawar dimulai dari ujung daun hingga bagian tengah. Ciri hawar daun ialah berwarna kuning hingga putih keabu-abuan. Sampel disimpan dalam kantung kertas dan diberi label identitas berupa jenis varietas, daerah/ lokasi, dan tanggal pengambilan.

\section{Isolasi dan Identifikasi Bakteri}

Isolasi bakteri $X$. oryzae pv. oryzae dilakukan pada medium agar-agar Wakimoto (1000 mL ekstrak dari $300 \mathrm{~g}$ kentang, $17 \mathrm{~g}$ sukrosa, $7 \mathrm{~g}$ pepton, $0.5 \mathrm{~g} \mathrm{Ca}\left(\mathrm{NO}_{3}\right)_{2} \cdot 4 \mathrm{H}_{2} \mathrm{O}, 1 \mathrm{~g}$ $\mathrm{Na}_{2} \mathrm{HPO}_{4} \cdot 12 \mathrm{H}_{2} \mathrm{O}, 17 \mathrm{~g}$ agar-agar bakto). Daun bergejala dipotong berukuran $1 \mathrm{~cm} \times 1 \mathrm{~cm}$ dan direndam dalam etanol $70 \%$ selama 2 menit. Potongan daun dibilas air steril dan direndam kembali dalam air steril selama 2 menit; selanjutnya suspensi bakteri diencerkan secara berseri sampai pengenceran $10^{-5}$. Sebanyak $100 \mu \mathrm{L}$ suspensi disebar pada medium agaragar Wakimoto dan diinkubasi pada suhu ruang selama 3-5 hari. Bentuk koloni tunggal yang tumbuh dan menunjukkan morfologi berwarna kuning, bulat, dan tepian rata diduga sebagai bakteri $X$. oryzae pv. oryzae. Koloni tersebut dimurnikan pada medium agar-agar Wakimoto dan dibuat biakan stok untuk identifikasi secara molekuler.

Identifikasi bakteri dilakukan dengan teknik PCR koloni. Sebanyak $100 \mu \mathrm{L} \mathrm{ddH}_{2} \mathrm{O}$ dimasukkan ke dalam tabung eppendorf $1.5 \mathrm{~mL}$, ditambahkan 1 loop bakteri, dan diinkubasikan pada suhu $95{ }^{\circ} \mathrm{C}$ selama 10 menit. Metode ini merupakan modifikasi dari metode Dafa'alla et al. (2000) yang ditambah dengan proses inkubasi pada penangas air pada suhu $65{ }^{\circ} \mathrm{C}$ selama 2 jam (setiap 10 menit dibolak-balik). Supernatan yang diperoleh digunakan sebagai templat DNA. Amplifikasi DNA dilakukan menggunakan 1 pasang primer spesifik, yaitu XOR-F (5'-GCATGACGTCATCGTCCTGT-3') dan XOR-R2 (5-CTCGGAGCTATATGCC GTGC-3') (Adachi dan Oku 2000; Keshavarz et al. 2011). Reaksi PCR tediri atas $10.5 \mu \mathrm{L}$ Go Taq ${ }^{\circledR}$ green Master Mix (Promega), $9.5 \mu \mathrm{L}$ $\mathrm{ddH}_{2} \mathrm{O}, 2 \mu \mathrm{L}$ templat DNA, $1.5 \mu \mathrm{L}$ primer forward XOR-F pada $10 \mathrm{pM}, 1.5 \mu \mathrm{L}$ primer reverse XOR-R2 pada $10 \mathrm{pM}$. Amplifikasi 
PCR dilakukan pada suhu denaturasi awal $95{ }^{\circ} \mathrm{C}$ selama 2 menit sebanyak 1 siklus, selanjutnya berturut-turut denaturasi pada suhu $95{ }^{\circ} \mathrm{C}$ selama 30 detik, penempelan pada suhu $63{ }^{\circ} \mathrm{C}$ selama 30 detik, dan pemanjangan DNA pada suhu $72{ }^{\circ} \mathrm{C}$ selama 1 menit sebanyak 29 siklus; pemanjangan DNA terakhir selama 7 menit pada suhu $72^{\circ} \mathrm{C}$. Hasil amplifikasi dianalisis menggunakan elektroforesis pada gel agarosa $1.5 \%$ dengan tegangan 100 Volt DC selama 30 menit. Hasil elektroforesis divisualisasi menggunakan gel doc (UVITEC) (Cambridge). Galur bakteri yang teramplifikasi pada $470 \mathrm{pb}$ dinyatakan positif $X$. oryzae pv. oryzae.

\section{Pengelompokan Patotipe Bakteri Xanthomonas oryzae pv. oryzae}

Galur bakteri yang positif $X$. oryzae pv. oryzae dari hasil amplifikasi DNA diperbanyak dan digunakan untuk inokulasi pada 5 varietas padi diferensial yang masing-masing telah memiliki gen ketahanan yang berbeda (Kozaka 1969). Inokulasi bakteri dilakukan dengan cara clip-method, yaitu memotong ujung daun tanaman padi sekitar 2-3 cm menggunakan gunting yang telah dicelupkan dalam suspensi $X$. oryzae pv. oryzae berumur 48 jam dengan konsentrasi $10^{8}-10^{9} \mathrm{cfu} \mathrm{mL}^{-1}$. Tanaman padi tersebut disungkup plastik dan diinkubasi pada suhu ruang. Pengamatan terhadap kemunculan gejala penyakit dilakukan 14 hari setelah inokulasi (HSI). Peubah yang diamati ialah panjang bercak dan panjang daun. Nisbah panjang bercak dibandingkan dengan panjang daun yang diinokulasi merupakan intensitas penyakit (IP).

$$
\mathrm{IP}=\frac{\mathrm{a}}{\mathrm{b}} \times 100 \%, \text { dengan }
$$

a, panjang gejala/bercak HDB (cm); dan b, panjang daun yang diinokulasi $(\mathrm{cm})$. Tanaman yang memiliki IP $<11 \%$ dikategorikan tahan, sedangkan $\geq 11 \%$ dikategorikan rentan.

\section{Analisis Sikuen DNA}

DNA bakteri hasil amplifikasi positif $X$. oryzae pv. oryzae dikirim ke Laboratorium First Base Asia, Malaysia. Runutan nukleotidanya dianalisis dengan bantuan program basic local alignment search tool (BLAST) pada situs national center for biotechnology information (NCBI).

Sebanyak 7 produk PCR dari hasil identifikasi galur $X$. oryzae pv. oryzae, yang masing-masing mewakili kabupaten tempat pengambilan sampel digunakan sebagai bahan input untuk analisis filogenetika guna menentukan kemiripannya dengan galur pada pusat data GenBank. Konstruksi pohon filogenetika dilakukan menggunakan program Mega 6.

\section{HASIL}

\section{Galur Xanthomonas oryzae pv. oryzae}

Sebanyak 75 galur bakteri diperoleh dari sampel daun padi. Galur bakteri dikelompokkan berdasarkan warna koloni, yaitu: 33 putih, 3 oranye, dan 39 kuning. Galur bakteri yang berwarna kuning diidentifikasi lanjut menggunakan teknik molekuler. Berdasarkan hasil pembandingan dengan program BLAST menunjukkan tingkat homologi yang mencapai $99.5-100 \%$ terhadap bakteri $X$. oryzae pv. oryzae yang berasal dari negara lain seperti Cina, Korea, India, Jepang, dan Amerika.

Berdasarkan hasil identifikasi molekuler diketahui tidak semua galur yang berwarna kuning ialah $X$. oryzae pv. oryzae. Hasil amplifikasi DNA terhadap 39 galur bakteri berwarna kuning menunjukkan hanya 29 galur yang menghasilkan pita DNA berukuran $470 \mathrm{pb}$ (Gambar 1). Galur-galur tersebut tersebar di 7 kabupaten di Sulawesi Selatan. Berdasarkan hasil analisis filogenetika terhadap 7 galur yang masing-masing mewakili satu kabupaten, terlihat bahwa 7 galur bakteri $X$. oryzae pv. oryzae memiliki kemiripan dengan $X$. oryzae pv. oryzae dari Amerika Serikat, Cina, Korea, Jepang dan India dengan nilai bootstrap 0.000-0.001 (Gambar 2).

\section{Patotipe Xanthomonas oryzae pv. oryzae}

Pengelompokan patotipe dari 29 galur menghasilkan 3 kelompok patotipe yang berbeda. Patotipe III menginfeksi 5 varietas padi, yaitu: Cisadane, Ketan, Cigeulis, 


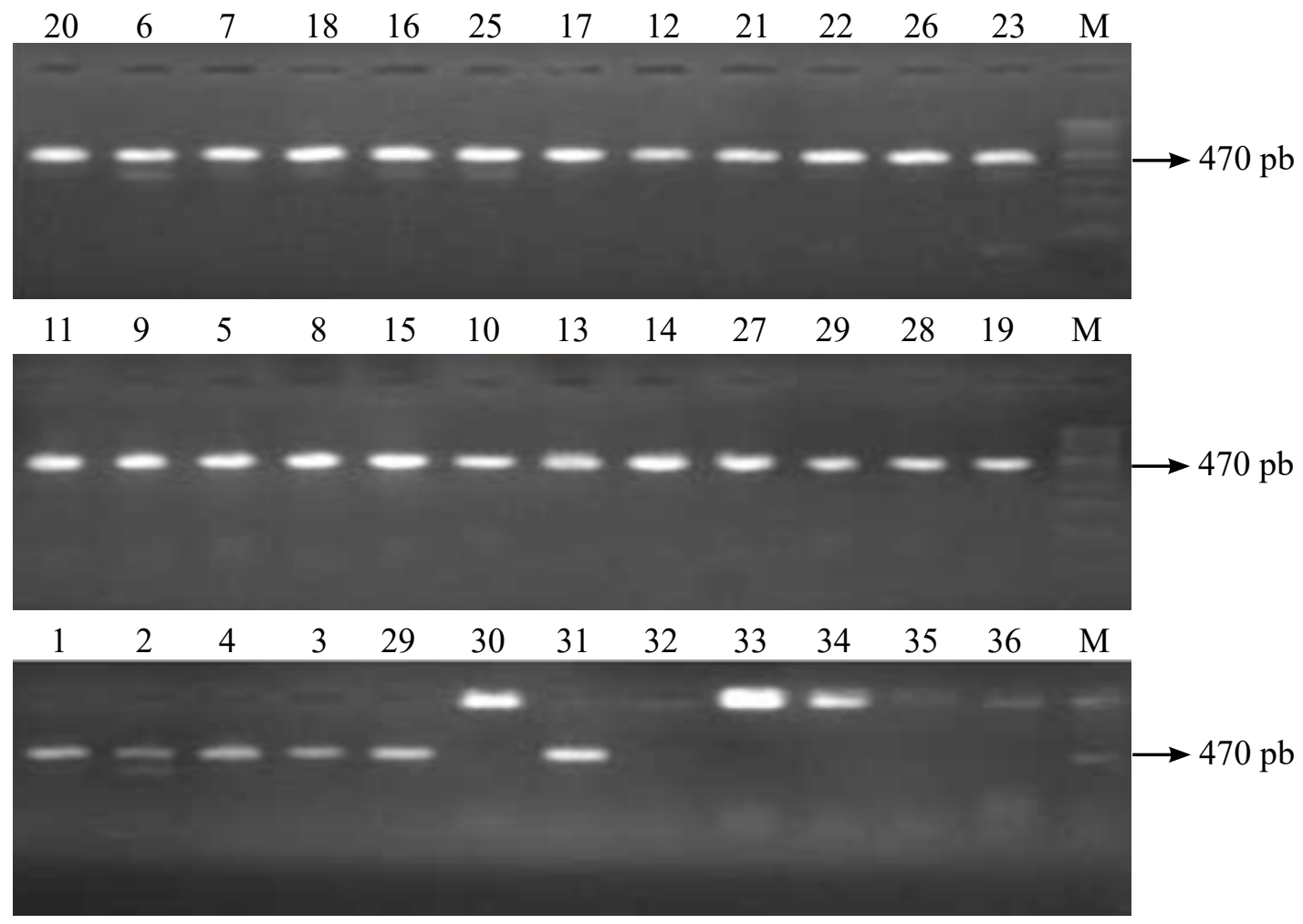

Gambar 1 Hasil amplifikasi produk PCR koloni menggunakan primer XOR-R2/XOR-F terhadap galur yang diduga Xanthomonas oryzae pv. oryzae. Angka di atas pita DNA menunjukkan nomor kode isolat seperti tercantum pada Tabel 1; M, Penanda DNA 100 pb; Nomor 29-36 berturut-turut ialah Xo113Jpt, Isolat (Iso) 101Mrs, Kontrol +, Iso069Bn, Iso080Btg, Iso066Br, Iso052Tkl dan Iso053Tkl.

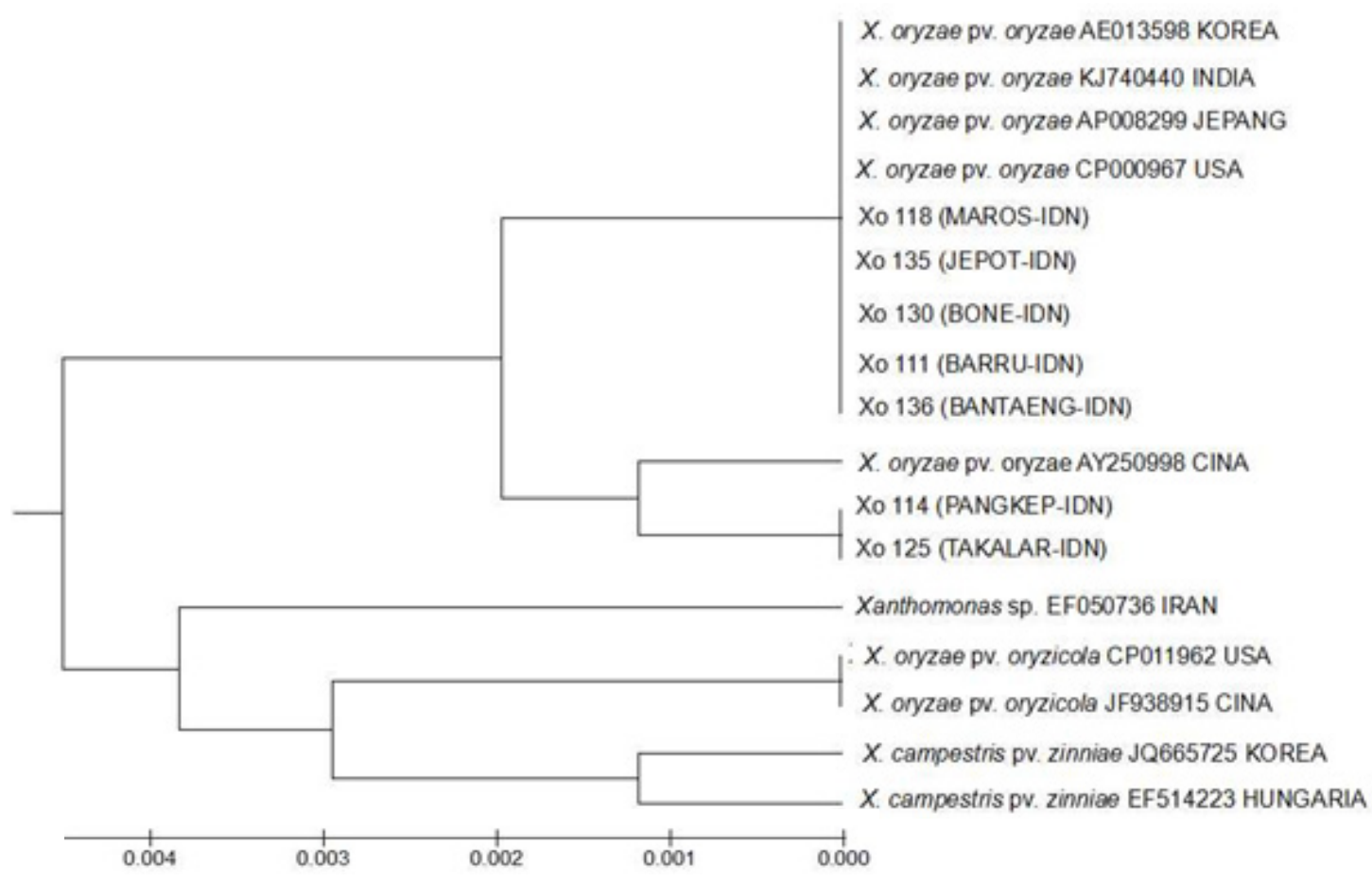

Gambar 2 Pohon filogenetika bakteri Xanthomonas oryzae pv. oryzae asal Sulawesi Selatan dengan negara lain berdasarkan logaritma UPGMA (bootstrap 1000 kali ulangan). 
Cisantana, dan Membramo (Tabel 1). Patotipe IV menginfeksi 14 varietas padi, yaitu: Cisantana, Ciliwung, Cisadane, Inpari 31, Inpari 4, Inpari 28, Inpari 3, Inpari 23, Inpari 9, IR64, Camindi, Cigeulis, Ciherang, dan Ketan; dan patotipe XII pada 2 varietas padi, yaitu: Cisadane dan Inpari 9. Padi varietas Cisadane dapat diinfeksi oleh ketiga patotipe tersebut (Tabel 1).

Balai Besar Penelitian Tanaman Padi (BB Padi 2017) menyatakan bahwa padi varietas Inpari 3 dan 9 agak tahan terhadap patotipe III, tetapi agak rentan terhadap patotipe IV dan VII. Varietas Inpari 4 dinyatakan agak tahan patotipe III dan IV, tetapi agak rentan terhadap patotipe VIII. Varietas Inpari 23 memiliki sifat tahan terhadap patotipe III, agak tahan terhadap patotipe IV, tetapi rentan terhadap patotipe VIII. Varietas Inpari 28 tahan terhadap patotipe III tetapi agak rentan terhadap patotipe IV dan VII. Varietas Inpari 31 dinyatakan tahan terhadap patotipe III dan agak tahan terhadap patotipe IV dan VIII.

\section{PEMBAHASAN}

Galur X. oryzae pv. oryzae pada medium Wakimoto mempunyai koloni bakteri dengan ciri berwarna kuning. Hal tersebut merupakan ciri yang mendasar dari genus Xanthomonas yang mengandung xantomonadin sehingga menghasilkan pigmen berwarna kuning, demikian juga pada $X$. oryzae pv. oryzicola (Lang et al. 2010; Onasanya et al. 2010). Selain Xanthomonas terdapat bakteri lain yang juga mampu menghasilkan pigmen berwarna kuning sehingga diperlukan teknik lain untuk menunjang keakuratan identifikasi. Oleh karena itu, identifikasi dengan teknik molekuler menggunakan primer spesifik diperlukan untuk mengidentifikasi $X$. oryzae pv. oryzae.

Berdasarkan hasil sikuen DNA yang dianalisis dengan program BLAST, terlihat bahwa galur bakteri asal Sulawesi Selatan menunjukkan tingkat kesamaan yang tinggi terhadap galur $X$. oryzae pv. oryzae yang terdapat di Cina, Korea, India, Jepang, dan Amerika dengan nilai homologi 95-100\%.
Besarnya persentase kelompok patotipe IV yang ditemukan menunjukkan bahwa patotipe ini dominan menginfeksi tanaman padi di Sulawesi Selatan. Berbeda halnya dengan Kabupaten Pangkep dan Takalar ditemukan patotipe baru yang muncul, yaitu patotipe XII, meskipun patotipe IV tetap mendominasi. Patotipe XII merupakan patotipe yang tingkat virulennya diduga lebih tinggi daripada patotipe yang sudah ada karena gen virulennya dapat mengatasi banyak gen ketahanan yang dimiliki oleh tanaman. Gen tersebut adalah PthXo1, PthXo2, dan PthXoS yang dikode oleh kelompok gen AvrBs3/PthA yang mampu berkontribusi secara spesifik untuk mematahkan banyak gen ketahanan tanaman inang seperti Xa5, Xa7, dan Xa21 (Hifni dan Kardin 1998).

Pergeseran patotipe $X$. oryzae pv. oryzae terjadi disejumlah daerah yang berbeda di daerah Sulawesi Selatan seperti di Kabupaten Bone yang awalnya didominasi oleh patotipe III (Khaeruni dan Wijayanto 2013) sekarang berubah dan didominasi oleh patotipe IV. Beberapa daerah ternyata tidak mengalami perubahan jenis patotipe $X$. oryzae pv. oryzae, seperti yang terjadi di kabupaten Maros yang masih didominasi oleh patotipe IV (Yuliani et al. 2012). Hal ini menunjukkan bahwa perbedaan wilayah tidak memengaruhi keberadaan atau infeksi patotipe pada padi.

Setiap wilayah pertanaman padi yang terinfeksi $X$. oryzae pv. oryzae dalam penelitian ini tidak diinfeksi oleh satu jenis patotipe meskipun ada kelompok patotipe yang dominan. Adanya dominasi patotipe yang terjadi membuktikan bahwa perkembangan dan perubahan patotipe dapat terjadi disetiap wilayah pertanaman yang memungkinkan patogen dapat berkembang dan tidak memiliki kisaran wilayah tertentu.

Sudir dan Suprihanto (2006) melaporkan perubahan patotipe dapat terjadi dalam jangka waktu dua musim tanam. Namun hasil penelitian mereka tidak melaporkan perubahan patotipe meskipun dihasilkan patotipe XII yang tergolong baru terdapat di wilayah Sulawesi Selatan. Tingkat persentase patotipe tersebut di Kabupaten Pangkep dan 


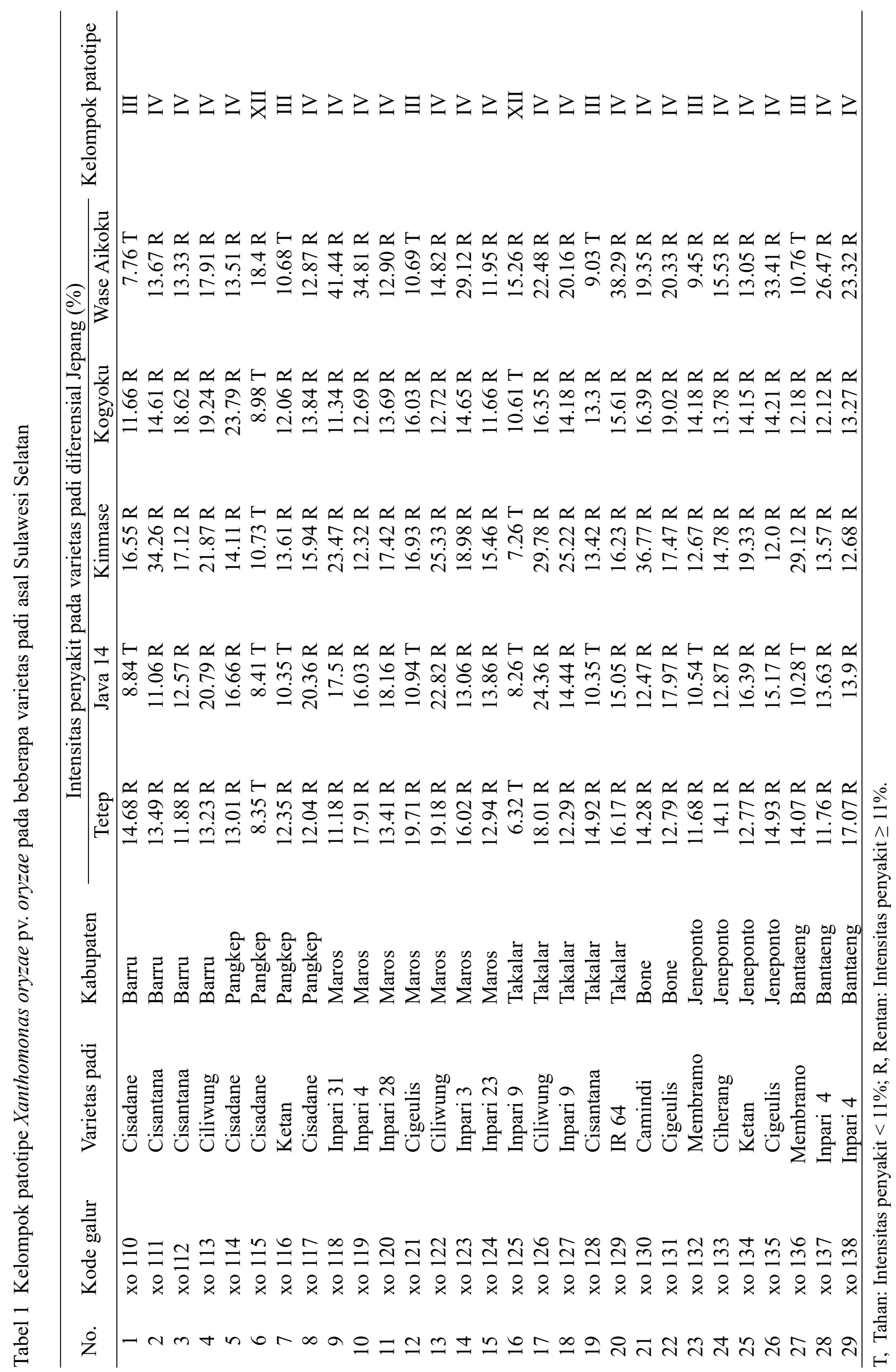


Takalar hanya $6.8 \%$. Munculnya patotipe XII pada area pertanaman padi di beberapa wilayah di Sulawesi Selatan menunjukkan adanya pergeseran patotipe yang berkembang pada lahan pertanian meskipun tidak besar. Hal tersebut menjadi perhatian baru dalam proses evaluasi perkembangan patotipe bakteri dalam pergeseran patotipe di lapangan.

Berdasarkan kondisi yang ditemukan dalam penelitian ini, evaluasi perkembangan patotipe bakteri X. oryzae pv. oryzae senantiasa diperlukan sebagai acuan dalam pengendalian penyakit tanaman padi. Besarnya pengaruh varietas tanaman padi yang menjadi komponen utama dalam teknik pengendalian merupakan acuan dalam tindakan evaluasi terhadap pergeseran patotipe yang sewaktuwaktu dapat berubah sehingga pemantauan tetap perlu dilakukan.

\section{DAFTAR PUSTAKA}

Adachi N, Oku T. 2000. PCR-mediumted detection of Xanthomonas oryzae pv. oryzae by amplification of the $16 \mathrm{~S}-23 \mathrm{~S}$ rDNA spacer region sequence. J General Plant Pathol. 66(4):303-309. DOI: https:// doi.org/10.1007/PL00012969.

[BB Padi] Balai Besar Penelitian Tanaman Padi. 2017. Inbrida Padi Sawah (Inpari). bbpadi.litbang.pertanian.go.id/index.php/ varietas/inbrida-padi-sawah-irigasi-inpari [diakses 22 Maret 2017].

Dafa'alla TH, Hobom G, Zahner H. 2000. Direct colony identification by PCRminiprep. J Mol Biol. 1(3):65-66.

Hifni HR, Kardin K. 1998. Pengelompokan isolat Xanthomonas oryzae pv. oryzae dengan menggunakan galur isogenik padi IRRI. J Hayati. 5(3):66-72.

Keshavarz K, Sijam K, Abidin MHZ, Habibudin H, Nazerian E. 2011. Rapid identification and differentiation of Xanthomonas oryzae pv. oryzae strain with primer 16S-23S rDNA from the rice fields in Peninsular Malaysia. J Plant Pathol. 5:93-99. DOI: https://doi.org/10.3923/ ajppaj.2011.93.99.
Khaeruni A, Wijayanto T. 2013. Pathotype grouping of Xanthomonas oryzae pv. oryzae isolates from South Sulawesi and Southeast Sulawesi. J Agr Sci Agrivita. 35(2):138-144. DOI: https:// doi.org/10.17503/Agrivita-2013-352-p138-144.

Kozaka T. 1969. Control of rice disease with resistant varieties. J Agr Hort. 44(1):208212.

Lang JM, Hamilton JP, Diaz MGQ, Sluys V, Burgos MRG, MC Cruz V, Buell CR, Tisserat NA, Leach JE. 2010. Genomicbased diagnostic marker development for Xanthomonas oryzae pv. oryzae and Xanthomonas oryzae pv. oryzicola. J Ame Phytopathol Soc. 94(3):311-319. DOI: https://doi.org/10.17503/Agrivita-201335-2-p138-144.

Mew TW, Vera C, Rayes RC. 1982. Interaction of Xanthomonas campestris oryzae and resistance of rice cultivar. Phytopathology. 72(7):786-789. DOI: https://doi.org/10.1094/Phyto-72-786.

Onasanya A, Basso A, Somado E, Gasore ER, Nwilene FE, Ingelbrecht I, Lomo J, Wydr K, Ekperigin MM, Langa M. 2010. Development of combined molecular diagnostic and DNA fingerprinting technique for rice bacteria pathogens in Africa.JBiotech.9(2):89-105.DOI:https:// doi.org/10.3923/biotech.2010.89.105.

Sudir, Nuryanto B, Triny. 2012. Epidemiologi, patotipe, dan strategi pengendalian penyakit hawar daun bakteri pada tanaman padi. J Tanaman Pangan. 7(2):79-87.

Sudir, Suprihanto. 2006. Perubahan virulensi strain Xanthomonas oryzae pv. oryzae penyebab penyakit hawar daun bakteri pada tanaman padi. J Penelitian Tanaman Pangan. 25(2):100-107.

Suryadi Y, Kadir TS, Machmud M. 2006. Deteksi Xanthomonas oryzae pv. oryzae penyebab hawar daun bakteri pada tanaman padi. J Tanaman Pangan. 25(2):108-115.

Yuliani D, Faizal A, Sudir. 2012. Identifikasi patotipe Xanthomonas oryzae pv. oryzae penyebab penyakit hawar daun bakteri 
padi di sentra produksi padi di Sulawesi Selatan. Di dalam: Buku I: Prosiding Seminar Ilmiah Hasil Penelitian Padi Nasional 2011.2011 Jul 27-28. Sukamandi (ID): Besar Penelitian Tanaman Padi. hlm 121-130. 